九州大学学術情報リポジトリ

Kyushu University Institutional Repository

Prognostic value of chromosomal translocations in small-bowel diffuse large B-cell lymphoma

池上，幸治

ht tp://hdl. handle. net/2324/1654747

出版情報 : 九州大学，2015，博士（医学），課程博士

バージョン:

権利関係：やむを得ない事由により本文ファイル非公開（2） 
論 文名：Prognostic value of chromosomal translocations in small-bowel diffuse large B-cell lymphoma

\section{(びまん性大細胞型 $\mathbf{B}$ 細胞リンパ腫における染色体転座の予後的重要性)}

区 分：甲

論文内容の要旨

本試験の目的は小腸びまん性大細胞型 B 細胞リンパ腫（DLBCL）患者における特に免疫 グロブリン重鎖遺伝子 $(I G H)$ 座を含むリンパ腫関連染色体転座の発生率および臨床的有 意性を調査することであった。原発性小腸 DLBCL 患者 35 例におけるパラフィン包埋組織 に対する間期蛍光 in situ ハイブリダイゼーションを用いて、IGH、BCL6、MYC および BCL2 を含む転座を調査し、全生存（OS）および無増悪生存（PFS）率をカプランーマイヤー法に より評価した。IGH、BCL6、MYC および BCL2 を含む転座が、33 例中それぞれ 23 例 $(70 \%) 、$ 12 例 $(36 \%) 、 8$ 例（24\%）および6例（18\%）で検出された。 $I G H$ 転座を有する患者は、 有しない患者よりリンパ腫の再発または進行の頻度が低かった（17\%対 60\%、 $\mathrm{P}=0.034 ） 。$ 単変量解析により、若齢、低い国際予後指標、IGH を含む転座、MALTI/BCL2 の過剩コピ 一、および BCL6 免疫発現が、より良好な OS およびPFS に有意に関連することが示され た。コックス多変量解析により、IGH を含む転座は、OS では有意差が認められなかったも のの良好な PFS の独立した予後因子であることが明らかになった。IGH を含む転座は、小 腸 DLBCL 症例では多くみられる。これらの転座は、良好な臨床経過を予測する可能性が ある。 